\title{
Missing links: a review of methods used to estimate trophic links in soil food webs
}

\author{
David Evans Walter, David T. Kaplan and Thomas A. Permar \\ Subtropical Plant Pathology, U.S. Department of Agriculture, Agricultural Research Service, 2120 \\ Camden Road, Orlando, FL 32803 (U.S.A.)
}

(Accepted for publication 5 July 1990 )

\begin{abstract}
Walter, D.E., Kaplan, D.T. and Permar, T.A., 1991. Missing links: a review of methods used to estimate trophic links in soil food webs. Agric. Ecosystems Environ., 34: 399-405.

Analysis of trophic interactions in soil food webs requires methods for obtaining reliable trophic information and organizing that information into functional units. Methods of obtaining trophic information about soil organisms fall into three general categories: (I) direct observation; (II) gut content analysis; (III) experiment/inference. Trophic information is interpreted using two conceptual models: (1) food webs (i.e. maps of feeding relationships among trophic species); (2) trophic levels (i.e. sequentially diminishing energy levels). Trophic classifications often confound these two conceptual models by defining an organism's feeding behavior in terms of trophic levels (e.g. herbivore, carnivore, detritivore) or pseudotrophic levels (e.g. fungivore, nematophage, insectivore). Simplistic trophic classifications miss many of the links in real food webs, result in theory based on false assumptions and limit the application of ecological principles to applied research.
\end{abstract}

\section{INTRODUCTION}

The ecological literature is replete with terms classifying organisms by their feeding behavior, e.g. autotroph, herbivore, carnivore, detritivore, fungivore, etc., but the actual trophic behavior implied by these terms is often unclear. Because of the opaque nature of soil and the prevalence of minute organisms in soil food webs, obtaining trophic information about soil organisms is often very difficult. To compensate for this problem, a variety of techniques for determining the feeding behavior of soil animals have been developed.

Once feeding information about a soil organism has been obtained, it must be integrated into a model. Two conceptual models are used to visualize trophic relationships: food webs and trophic levels. A food web is a map of feeding relationships among species (or trophic species sensu; Briand and Cohen, 1987) that can include energy fluxes and functional dynamics (Paine, 1980 ). Trophic levels represent the sequential transformations of energy that 
occur when one organism feeds on another (Burns, 1989). When simplified trophic classifications are used that confound these two conceptual models, both the real feeding relationships of organisms and the relationship of these feeding habits to trophic level energetics are obscured. This is especially true in soil systems, where many species are opportunistic generalists that obtain energy at several trophic levels (Anderson and Healy, 1972; Small, 1987; Walter, 1987; Moore et al., 1988).

The purpose of this paper is (1) to review techniques used to obtain trophic information about consumers in soil fuod webs, and (2) to demonstrate that confounding trophic level energetics with trophic classification obscures food web structure.

\section{METHODS USED TO ESTIMATE LINKS IN SOIL FOOD WEBS}

\section{Direct observation}

Organisms that feed on or in a discrete resource can be observed feeding from field collections, e.g. nematodes, arthropods and fungi that attack plant roots or fungal fruiting bodies. Not all organisms associated with a discrete resource necessarily feed on that resource, however. For example, Aphelenchus avenae Bastian, a nematode often associated with plant roots, may feed on plant cells, but more typically feeds on plant pathogenic fungi or secondary invaders associated with root cells (Poinar, 1983). Moreover, confirmation of feeding on a discrete resource does not exclude feeding on other resources at other times or at other stages in a life cycle; e.g. Ditylenchus destructor Thorne, the potato rot nematode, is parasitic on the roots of $>60$ species of plants and it can also be reared on $>65$ species of fungi (Esser and Smart, 1977).

Rhizotrons, biotrons and other methods of viewing intact soil can be used to observe feeding behavior in the field (Fogel and Lussenhop, 1991). Biotrons are expensive to construct, require extensive investments in observational time in either direct observation or reviewing camera observations, and it is often difficult to determine the exact identity of the organisms involved and the extent of the interaction.

Point-in-time observations of a soil organism feeding or in association with a resource can be obtained by quick freezing, embedding and sectioning of baits or soil cores (Pande and Berthet, 1973; Anderson, 1978). Although the organisms involved can often be precisely determined, sectioning is labor intensive and difficult to interpret.

The cornerstone of trophic analysis in soil biology has been laboratory observation and culturing. Laboratory observations are usually made with resources chosen by the investigator and with animals held in a container with an artificial substrate (e.g. agar or charcoal-plaster) that allows easy obser- 
vation of the organism, but does not mimic the three-dimensional structure of the soil (Walter and Ikonen, 1989). The use of a cool light source (e.g. fiber optic illumination) and high magnifications $(>100 \times)$ greatly increases the ease and precision of observations. Inverted microscopes can be especially useful (Walter and Kaplan, 1990) (Table 1). Successful culturing requires the discovery of adequate food resources for all life stages of an animal, but does not guarantee that the animal will feed on these resources in nature.

\section{Gut content analysis}

Direct microscopic examination of guts (Anderson and Healy, 1972) or feces can be performed if animals ingest solid food, preferably engulfing entire prey items or at least large pieces of a food resource, since identification of highly fragmented remains is difficult. Unfortunately, those parts of an animal's diet that resist digestion (e.g. arthropod cuticle, fungal spores) are overestimated, fragile items (e.g. nematode cuticle) are underestimated and prey fluids cannot be evaluated in gut content examinations.

Electrophoresis is used to identify proteins, enzymes or other prey-derived gut constituents even in those predators which feed only on fluids, e.g. identification of diagnostic esterase band patterns representing prey cell contents (Murray and Solomon, 1978).

Serological assays (Greenstone, 1989) using polyclonal and monoclonal

\section{TABLE 1}

Diet of the mite $S$. rocketti in rotting citrus roots ${ }^{1}$

\begin{tabular}{rllc}
\hline $\begin{array}{l}\text { Percent mites } \\
\text { feeding on }\end{array}$ & Food type & Trophic classification & Mite trophic level \\
\hline 100 & $\begin{array}{l}\text { Slurry } \\
\text { (root } \\
\text { fragments + bacteria) }\end{array}$ & $\begin{array}{l}\text { Detritivore } \\
\text { /bacteriovore }\end{array}$ & $2+3$ \\
22 & $\begin{array}{l}\text { Decomposer fungi } \\
4\end{array}$ & Fungivore & 3 \\
4 & Phytonematode & Predator & 3 \\
22 & Microbivore & Predator & 4 \\
22 & Nematode & Predator & 4 \\
22 & Protozoa & Necrophage/fungivore & $4+5$ \\
& Nematodes & Fungivore & 5 \\
\hline
\end{tabular}

'Citrus roots which had been incubated for 1 week at $25^{\circ} \mathrm{C}$ were shaken in $40 \mathrm{ml}$ water to produce a suspension of decaying root fragments and associated organisms. This suspension was centrifuged at $700 \times g$ and the resulting pellet was plated on a $1-\mathrm{mm}$ thick layer of water agar in a $9-\mathrm{cm}$ petri dish. An inverted microscope at $200-400 \times$ was used to examine the feeding behavior of a total of 23 mites for a total of $281 \mathrm{~min}$. Mite trophic level = prey level +1 . 
(MAb) antibodies have been developed for the identification of a number of microbial and nematode root pathogens. Some of these assays may be adapted to identify plant parasites in the gut contents of their predators. Data presented in Table 2 (Permar and Walter, unpublished) demonstrate the specificity and sensitivity of a MAb-based, enzyme-linked immunosorbent assay (ELISA) for detecting mite predation of burrowing nematode.

Feeding behavior can also be determined by tagging of prey with dyes or radionucleotides (Coleman and McGinnis, 1970; McBrayer and Reichle, 1971).

\section{Experiment/inference}

Experimental manipulation can be used to infer feeding behavior through population changes measured by sequential sampling, and is an important tool for evaluating the strength and importance of these behaviors (Elliott et al., 1980, 1986). Examples are gnotobiotic experiments in which known elements of the soil fauna are added to sterilized soil, and exclusion experiments in which specific segments of the soil fauna are either physically excluded or reduced using biocides (Coleman et al., 1978; Coleman, 1985).

The morphology of the feeding apparatus can be used to infer feeding. Soil nematodes, for example, are usually classified into four or five trophic groups based on the morphology of the stoma, but these delineations have rarely been tested and are not always accurate (Freckman, 1988).

Correlation, predator/prey ratios and indices of association can be used to infer trophic interactions (Ludwig and Reynolds, 1988).

\section{TABLE 2}

Use of an enzyme-linked immunosorbent assay (ELISA) and a monoclonal antibody (MAb) to differentiate feeding on a burrowing nematode (Radopholus citrophilus Huettel et al.) from feeding on a southern root-knot nematode (Meloidogyne incognita Kofoid \& White) by the predatory mite ( $L a-$ sioseius youcefi Athias)

\begin{tabular}{llll}
\hline $\begin{array}{l}\text { Mite } \\
\text { equivalents } \\
\text { per well }\end{array}$ & \multicolumn{2}{l}{ Absorbance $(405 \mathrm{~nm})$} & \\
\cline { 2 - 4 } & $\begin{array}{l}\text { Mites } \\
\text { starved }\end{array}$ & $\begin{array}{l}\text { Mites fed } R . \\
\text { citrophilus }\end{array}$ & $\begin{array}{l}\text { Mites fed } M . \\
\text { incognita }\end{array}$ \\
\hline 0.600 & 0.049 & 0.127 & 0.054 \\
0.300 & 0.052 & 0.130 & 0.056 \\
0.150 & 0.055 & 0.137 & 0.065 \\
0.075 & 0.015 & 0.086 & 0.031 \\
0.000 & 0.032 & 0.025 & 0.032 \\
\hline
\end{tabular}

Mite antigens were analyzed using an anti- $R$. citrophilus MAb in an indirect ELISA. An alkaline phosphatase-substrate complex was used to quantify the reaction on an automated microtiter plate reader for $0.1 \mathrm{ml}$ mite homogenate per well. Starved mites $(70 \mathrm{~h})$ had previously been fed on a rhabditid nematode. 


\section{INTEGRATION OF OBSERVATIONS INTO MODELS}

Once feeding behaviors have been estimated, they must be integrated into a community or ecosystem level model. The degree of resolution used will often be a function of the sophistication of the model, the goals of the analysis, or arbitrary decisions relating to clarity in figures or the importance of an interaction (Paine, 1988). Trophic levels represent steps of diminishing energy content between autotrophs and top consumers in a food web, and do not refer to species feeding behaviors (Odum, 1971). Unfortunately, many soil ecologists would prefer to acknowledge only simple, stepwise transfers of energy. This tendency to obscure actual functional relationships becomes especially absurd when feeding behaviors are elevated to pseudotrophic levels, e.g. treating insectivores or fungivores as trophic level classes. The messy nature of feeding biology is well illustrated by Schwiebea rocketti Woodring ( Table 1 ) (Walter and Kaplan, 1990). This animal obtains energy at many of the trophic levels present in the citrus rhizosphere food web, although most feeding occurs at a low trophic level.

Extensive omnivory (i.e. feeding at several trophic levels) has important implications for theoretical considerations of food web structure, stability and dynamics. Energy is more abundant at lower trophic levels, but essential nutrients may be in short supply (Thorn and Barron, 1984). Animals that obtain their nutritional and energy needs from a variety of sources should be well buffered against disturbance, and may be able to maintain higher population levels than organisms whose energy needs must be obtained at a single trophic level. We recently surveyed 27 citrus groves in Florida for microbial antagonists of plant-feeding nematodes; and all 27 sites contained nematophagous fungi (a total of 12 species) that feed on both decomposing plant matter and a variety of nematodes, obtaining energy at several trophic levels. Only one site was positive for a single monophagous parasite (i.e. restricted to energy sequestered from the trophic level(s) of its host). An organism that specializes on prey at a particular trophic level (if such prey exist) must be able to obtain a predictable supply of energy and essential nutrients within that trophic level. This would seem to require large, stable host populations and would set the stage for long-term co-evolutionary interactions. Perhaps this is why plants and herbivores tend to be more easily defined by trophic level parameters.

\section{CONCLUSIONS}

The most rigorous method for determining the trophic behavior of a species would be to observe a large number of individuals throughout their life cycles in a number of field habitats. Since this is often impractical, it is best to apply two or more techniques, with one acting as a check for the other. For 
example, Pugh and King (1985) used a combination of field observation, esterase electrophoresis and laboratory feeding experiments to estimate the feeding behaviors in an intertidal mite community. Experimental manipulation is the best method for evaluating the strength of observed or postulated trophic interactions.

It must be recognized that functional classifications such as detritivore, fungivore, nematophage, etc. do not directly translate into trophic levels. When we ignore links in food webs because of preconceptions about trophic level dynamics, we miss key components of food web structure. The complexity and apparently high degree of connectance in soil food webs have important implications for theoretical considerations of stability and persistence (Hunt et al., 1987; Moore et al., 1988). For applied soil ecology, elucidation of these "missing links" will influence the development of biological or cultural strategies to control root pathogens.

\section{DISCLAIMER}

Mention of a trademark, warranty, proprietary product, or vendor does not constitute a guarantee by the USDA and does not imply its approval to the exclusion of other products or vendors that may also be suitable.

\section{REFERENCES}

Anderson, J.M., 1978. The preparation of gelatin-embedded soil and litter sections and their application to some soil ecological studies. J. Biol. Educ., 12: 82-88.

Anderson, J.M. and Healy, I.N., 1972. Seasonal and inter-specific variation in major components of the gut contents of some woodland Collembola. J. Anim. Ecol., 41: 359-368.

Briand, F. and Cohen, J.E., 1987. Environmental correlates of food chain length. Science, 238: 956-960.

Burns, T.P., 1989. Lindeman's contradiction and the trophic structure of ecosystems. Ecology, 70: $1355-1362$.

Coleman, D.C., 1985. Through a ped darkly: an ecological assessment of root-soil-microbialfaunal interactions. In: A.H. Fitter (Editor), Ecological Interactions in Soil. Blackwell Scientific, Oxford, pp. 1-21.

Coleman, D.C. and McGinnis, J.T., 1970. Quantification of fungus-small arthropod food chains in the soil. Oikos, 21: 134-137.

Elliott, E.T., Anderson, R.V., Coleman, D.C. and Cole, C.V., 1980. Habitable pore space and microbial trophic interactions. Oikos, 35: 327-335.

Elliott, E.T., Hunt, H.W., Walter, D.E. and Moore, J.C., 1986. Microcosms, mesocosms and ecosystems: Linking the laboratory to the field. Proceedings of the 4th International Symposium on Microbial Ecology, at Ljublyana, Yugoslavia, pp. 472-480.

Esser, R.P. and Smart, G.C., 1977. Potato rot nematode, Ditylenchus destructor Thorne, 1945. Nematology Circular 28, Fla. Dep. Agric. Consumer Serv., D.P.I.

Fogel, R. and Lussenhop, J., 1991. A new light for soil biology: video analysis of root-soilmicrobial-faunal interactions. Agric. Ecosystems Environ., in press. 
Freckman, D.W., 1988. Bacterivorous nematodes and organic matter decomposition. Agric. Ecosystems Environ., 24: 195-217.

Greenstone, M.H., 1989. Foreign exploration for predators: A proposed new methodology. Environ. Entomol., 18: 195-200.

Hunt, H.W., Ingham, E.R., Ingham, R.E., Elliott, E.T., Moore, J.C., Rose, S.L., Reid, C.P.P. and Morley, C., 1987. The detrital food web in a shortgrass prairie. Biol. Fertil. Soils, 3: 5768.

Ludwig, J.A. and Reynolds, J.F., 1988. Statistical Ecology. A Primer on Methods and Computing. Wiley, New York.

McBrayer, J.F. and Reichle, D.E., 1971. Trophic structure and feeding rates of forest soil invertebrate populations. Oikos, 22: 381-388.

Moore, J.C., Walter, D.E. and Hunt, H.W., 1988. Arthropod regulation of micro-and mesobiota in belowground detrital food webs. Annu. Rev. Entomol., 33: 419-439.

Murray, R.A. and Solomon, M.G., 1978. A rapid technique for analysing diets of invertebrate predators by electrophoresis. Ann. Appl. Biol., 90: 7-10.

Odum, E.P., 1971. Fundamentals of Ecology. Saunders, London.

Paine, R.T., 1980. Food webs: linkage, interaction strength and community infrastucture. J. Anim. Ecol., 49: 667-685.

Paine, R.T., 1988. Food webs: road maps of interactions or grist for theoretical development. Ecology, 69: 1648-1654.

Pande, Y.D. and Berthet, P., 1973. Studies on the food and feeding habits of soil Oribatei in a black pine plantation. Oecologia (Berlin), 12:413-426.

Poinar, G.O., Jr., 1983. The Natural History of Nematodes. Prentice Hall, Englewood Cliffs, NJ.

Pugh, P.J.A. and King, P.E., 1985. Feeding in intertidal Acari. J. Exp. Mar. Biol. Ecol., 94: 269280.

Small, R.W., 1987. A review of the prey of predatory soil nematodes. Pedobiologia, 30: 179206.

Thorn, R.G. and Barron, G.L., 1984. Carnivorous mushrooms. Science, 224: 76-78.

Walter, D.E., 1987. Trophic behavior of "mycophagous" microarthropods. Ecology, 68: 226229.

Walter, D.E. and Ikonen, E.K., 1989. Species, guilds, and functional groups: taxonomy and behavior in nematophagous arthropods. J. Nematol., 21: 315-327.

Walter, D.E. and Kaplan, D.T., 1990. Feeding observations on two astigmatic mites, Schwiebea rocketti Woodring (Acaridae) and Histiostoma bakeri Hughes \& Jackson (Histiostomatidae), associated with citrus feeder roots. Pedobiologia, 34: 221-226. 